九州大学学術情報リポジトリ

Kyushu University Institutional Repository

\title{
Cultivar and Seasonal Differences in the Response of Non Pre-cooled Tulip Bulbs to Gibberellin, TIBA and Root Excision
}

Geng, Xing Min

Graduate School of Bioresource and Bioenvironmental Sciences, Kyushu University

Okubo, Hiroshi

Faculty of Agriculture, Kyushu University

Saniewski, Marian

Research Institute of Pomology and Floriculture, Poland

https://doi.org/10.5109/4664

出版情報: 九州大学大学院農学研究院紀要. 50 (2)，pp.503-509，2005-10-01. Faculty of Agriculture, Kyushu University

バージョン：

権利関係 : 


\title{
Cultivar and Seasonal Differences in the Response of Non Pre-cooled Tulip Bulbs to Gibberellin, TIBA and Root Excision
}

\author{
Xing Min GENG ${ }^{1 *}$, Hiroshi OKUBO \\ and Marian SANIEWSKI ${ }^{2}$
}

\author{
Laboratory of Horticultural Science, Division of Agricultural Botany, \\ Department of Plant Resources, Faculty of Agriculture, \\ Kyushu University, Fukuoka 812-8581, Japan \\ (Received June 16, 2005 and accepted July 26, 2005)
}

\begin{abstract}
Effects of $\mathrm{GA}_{3}, \mathrm{GA}_{3}$ with TIBA with/without root excision on growth and flowering of seven cultivars of non pre-cooled tulip bulbs were investigated. The treatments promoted the rapid growth and flowering of all the examined cultivars stored and grown at $20^{\circ} \mathrm{C}$, although there was cultivar and seasonal variations of the response. Cultivars of Darwin hybrid group showed the highest response to $\mathrm{GA}_{3}$ and $\mathrm{GA}_{3}+$ TIBA among the cultivars of other groups. The relationship between the duration of cold requirement of tulip bulbs and the response to the treatments with $\mathrm{GA}_{3}$ and $\mathrm{GA}_{3}$ +TIBA was suggested. The seasonal difference of the response to the treatments indicates the endogenous changes of metabolism in the bulbs during the storage.
\end{abstract}

\section{INTRODUCTION}

Studies on hormonal regulation of growth and flowering of tulips have been carried out so far by using the pre-cooled bulbs with non pre-cooled bulbs (control) (for example, Aung and De Hertogh 1967; Rebers et al., 1995), since the cool treatment gave the rapid growth and fastened the flowering that makes the comparison easy. Comparison using only the bulbs of non-cooling treatment has not yet been studied. Our approach is different from the past studies. We tried to induce growth and flowering in non pre-cooled bulbs by various means for the comparison with non treated non pre-cooled bulbs.

We previously clarified that 1 ) gibberellin $\mathrm{A}_{3}\left(\mathrm{GA}_{3}\right)$ partly replaced the cold requirement of non pre-cooled bulbs of tulip cv. Oxford, 2) when 2,3,5-triiodobenzoic acid (TIBA) was applied with $\mathrm{GA}_{3}$, the growth and flowering were more promoted, 3 ) the later the treatment with $\mathrm{GA}_{3}$ or $\mathrm{GA}_{3}$ + TIBA was, the faster the flowering was and the longer the flower stalk was, 4) excision of roots was more effective for early flowering and flower stalk elongation of the GA + TIBA treated bulbs when planted later, 5) naphthylphthalamic acid (NPA), another auxin transport inhibitor, with $\mathrm{GA}_{3}$ showed the similar effects to that of TIBA and 6) endogenous indole-3-acetic acid (IAA) content in the basal plate and lower internodes was higher with $\mathrm{GA}_{3}+$ TIBA treatment than with $\mathrm{GA}_{3}$ treat-

' Laboratory of Horticultural Science, Division of Agricultural Botany, Graduate School of Bioresource and Bioenvironmental Sciences, Kyushu University

: Research Institute of Pomology and Floriculture, Pomologiczna 18,96-100 Skierniewice, Poland

* Corresponding author (E-mail: gengxm@agr.kyushu-u.ac.jp) 
ment alone (Geng et. al., 2005). And we concluded that TIBA blocked the polar auxin transport at the basal plate and increased auxin content in the stems and the root excision brought the better absorption of $\mathrm{GA}_{3}$ from the cut surface, thereby promoted rapid internode elongation and flowering. Gibberellin-induced shoot growth and flowering of non pre-cooled derooted bulbs of tulip cultivars 'Apeldoorn' and 'Gudoshnik' has also been reported (Saniewski et al., 1999).

Cultivated tulips have been classified into 15 groups based upon the time of outdoor flowering, morphology of the perianth parts and their origin (De Hertogh et al., 1983). Cultivar difference in the time of outdoor flowering reflects the difference in low temperature requirement for subsequent growth and flowering, and this suggests the difference by cultivars or groups in the response to our treatments. In this study, effects of $\mathrm{GA}_{3}, \mathrm{GA}_{3}+\mathrm{TIBA}$ and root excision in different seasons were investigated.

\section{MATERIALS AND METHODS}

Seven cultivars of tulip (Tulipa gesneriana L.) bulbs (Table 2) with $12-13 \mathrm{~cm}$ circumferences, harvests of Niigata Prefecture, Japan in 2001, were used in this study. Upon arrival at the laboratory on 30 August the bulbs were disinfected with 1.0\% Benlate (Du Pont) for $1 \mathrm{~h}$ and stored at $20^{\circ} \mathrm{C}$ until the beginning of the experiments. The tunics were removed and 15 ('Oxford') or 10 (other cultivars) bulbs were used in each treatment. The cultivars covered early-flowering (Single early), mid-season flowering (Darwin hybrid and Triumph) and late-flowering (Single late) groups.

The bulbs were put on aluminum trays with distilled water (control), $200 \mathrm{mgl}^{-1} \mathrm{GA}_{3}$ solution or $200 \mathrm{mgl}^{-1} \mathrm{GA}_{3}$ solution after the lanolin paste containing $0.5 \%$ TIBA was smeared around the base of outer scale near the rim of root primordia of the bulbs with or without excision of the root primordia. The bulbs were held upright with plastic supports. They were grown on 6 September (except 'Kaiserin Maria Theresia') and 6 November at $15^{\circ} \mathrm{C}$ in the phytotron (natural daylength) of The Biotron Institute, Kyushu University and transferred to $20^{\circ} \mathrm{C}$ in the phytotron on the first day of the next month (1 October and 1 December, respectively). Water and $\mathrm{GA}_{3}$ solution were renewed every two or three days. Roots that emerged after planting from the derooted bulbs were removed. The flowering date was determined when the petals were fully colored, and three days later, length of internodes was measured.

\section{RESULTS}

\section{Response in September planting}

Flowering was observed only in 'Golden Empire State' and 'Oxford' of Darwin hybrid group when the bulbs were treated with $\mathrm{GA}_{3}$ or $\mathrm{GA}_{3}+\mathrm{TIBA}$ in September planting (Table 1). When the bulbs were treated with only $\mathrm{GA}_{3}$, flowering was observed in 'Oxford', but not in 'Golden Empire State'. The excision of the root primordia resulted in lower flowering rates, but it shortened the number of days to flowering of 'Golden Empire State' treated with $\mathrm{GA}_{3}+$ TIBA. 
Table 1. Effects of $\mathrm{GA}_{3}, \mathrm{GA}_{3}+$ TIBA and excision of roots on flowering of six cultivars of non pre-cooled tulip bulbs planted in September.

\begin{tabular}{|c|c|c|c|c|c|}
\hline Group ${ }^{2}$ & Cultivar & Treatment & Roots $^{y}$ & $\begin{array}{c}\text { Flowering } \\
\text { (\%) }\end{array}$ & $\begin{array}{c}\text { Days to } \\
\text { flowering }\end{array}$ \\
\hline \multirow[t]{6}{*}{$\mathrm{SE}$} & Merry Christmas & Water & + & 0 & - \\
\hline & & & - & 0 & - \\
\hline & & $\mathrm{GA}_{3}$ & + & 0 & - \\
\hline & & & - & 0 & - \\
\hline & & $\mathrm{GA}_{3}+$ TIBA & + & 0 & - \\
\hline & & & - & 0 & - \\
\hline \multirow[t]{12}{*}{$\mathrm{DH}$} & Golden Empire & Water & + & 0 & - \\
\hline & State & & - & 0 & - \\
\hline & & $\mathrm{GA}_{3}$ & + & 0 & - \\
\hline & & & - & 0 & - \\
\hline & & $\mathrm{GA}_{3}+\mathrm{TIBA}$ & + & 100 & $79.8 \pm 5.1^{\mathrm{x}}$ \\
\hline & & & - & 80 & $66.6 \pm 4.6$ \\
\hline & & Water & + & 0 & - \\
\hline & Oxford & & - & 0 & - \\
\hline & & $\mathrm{GA}_{3}$ & + & 80 & $83.3 \pm 10.3$ \\
\hline & & & - & 40 & $80.2 \pm 13.0$ \\
\hline & & $\mathrm{GA}_{3}+$ TIBA & + & 40 & $90.5 \pm 7.3$ \\
\hline & & & - & 13 & $92.5 \pm 3.5$ \\
\hline \multirow[t]{12}{*}{$\mathrm{T}$} & Kees Nelis & Water & + & 0 & - \\
\hline & & & - & 0 & - \\
\hline & & $\mathrm{GA}_{3}$ & + & 0 & - \\
\hline & & & - & 0 & - \\
\hline & & $\mathrm{GA}_{3}+\mathrm{TIBA}$ & + & 0 & - \\
\hline & & & - & 0 & - \\
\hline & Koki & Water & + & 0 & - \\
\hline & & & - & 0 & - \\
\hline & & $\mathrm{GA}_{3}$ & + & 0 & - \\
\hline & & & - & 0 & - \\
\hline & & $\mathrm{GA}_{3}+$ TIBA & + & 0 & - \\
\hline & & & - & 0 & - \\
\hline \multirow[t]{6}{*}{ SL } & Ile de France & Water & + & 0 & - \\
\hline & & & - & 0 & - \\
\hline & & $\mathrm{GA}_{3}$ & + & 0 & - \\
\hline & & & - & 0 & - \\
\hline & & $\mathrm{GA}_{3}+\mathrm{TIBA}$ & + & 0 & - \\
\hline & & & - & 0 & - \\
\hline
\end{tabular}

. SE; Single early, DH; Darwin hybrid, T; Triumph and SL; Single late.

y + ; rooted bulbs, - ; derooted bulbs.

; values \pm standard deviation.

\section{Response in November planting}

All the cultivars flowered when they were treated with $\mathrm{GA}_{3}$ or $\mathrm{GA}_{3}+$ TIBA in November planting (Table 2). 'Merry Christmas', 'lle de France' (Single early group) and 'Kaiserin Maria Theresia' (both Single late group) flowered even though their bulbs were 
Table 2. Effects of $\mathrm{GA}_{3}, \mathrm{GA}_{3}+\mathrm{TIBA}$ and excision of roots on flowering of seven cultivars of non pre-cooled tulip bulbs planted in November.

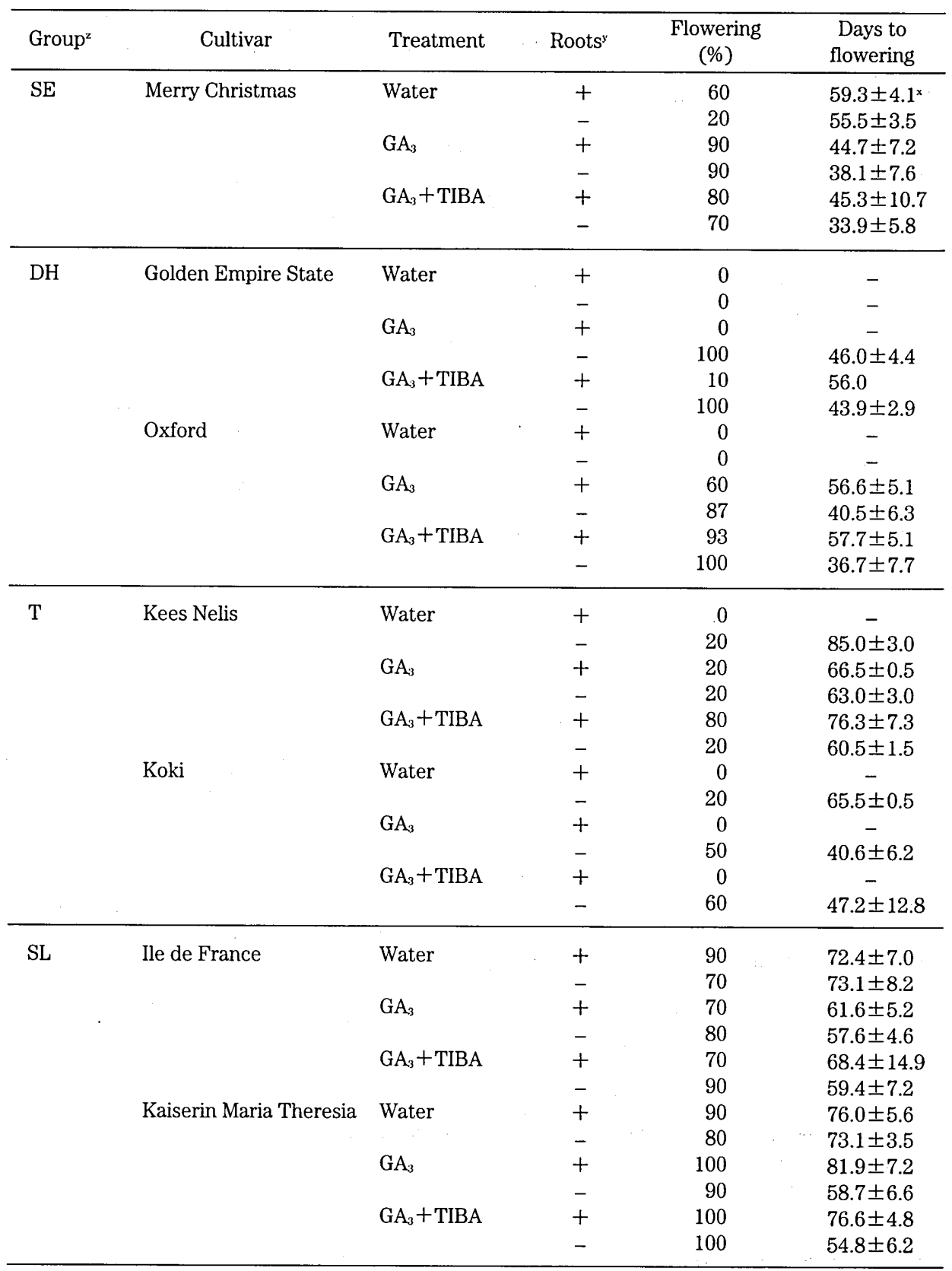

z SE; Single early, DH; Darwin hybrid, T; Triumph and SL; Single late.

+; rooted bulbs, - ; derooted bulbs.

; ; values \pm standard deviation. 
grown on water, although they took longer days for flowering than those treated with $\mathrm{GA}_{3}$ or $\mathrm{GA}_{3}+\mathrm{TIBA}$.

\section{Single early}

$\mathrm{GA}_{3}$ and $\mathrm{GA}_{3}$ + TIBA treatments fastened the flowering date by 15 and 14 days with roots, respectively and by 17 and 22 days without roots, respectively (Table 2). Derooted plants flowered seven and 11 days earlier than rooted plants with $\mathrm{GA}_{3}$ and $\mathrm{GA}_{3}+$ TIBA treatments, respectively, whereas the difference was only four days on water. All internodes were longer in derooted than in rooted plants with either $\mathrm{GA}_{3}$ or $\mathrm{GA}_{3}$ +TIBA treatments, resulting in longer flower stalk (Fig. 1).

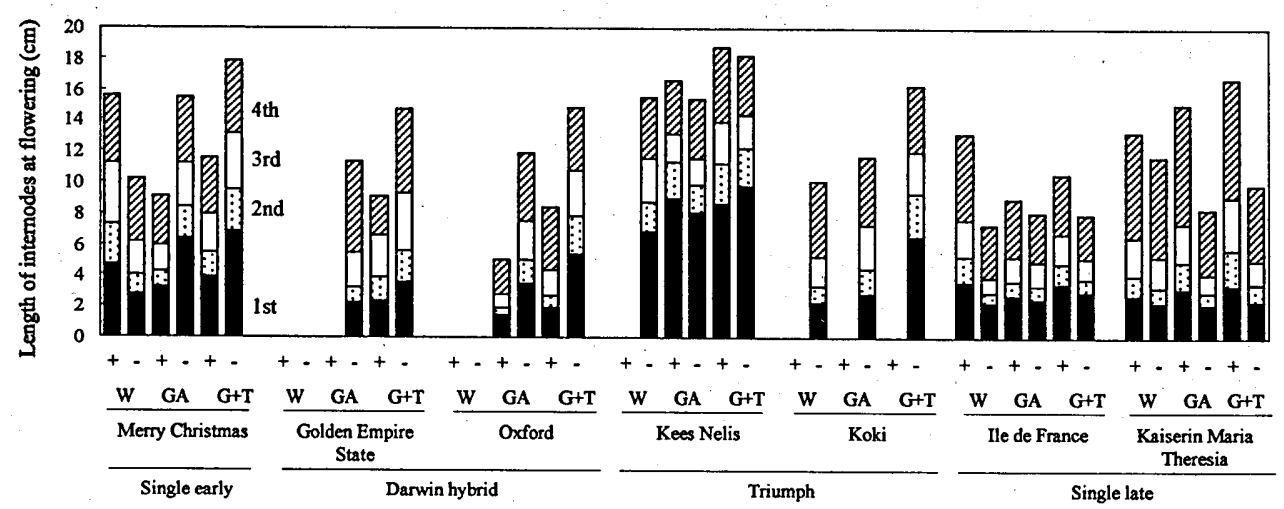

Fig. 1. Effects of $\mathrm{GA}_{3}, \mathrm{GA}_{3}+\mathrm{TIBA}$ and excision of roots on internode length at flowering of different cultivars of non pre-cooled tulip bulbs planted in November.

+ ; rooted, -; derooted.

W; water, $\mathrm{GA} ; \mathrm{GA}_{3}, \mathrm{G}+\mathrm{T} ; \mathrm{GA}_{3}+$ TIBA.

\section{Darwin hybrid}

No flowering was observed on water with or without roots (Table 2). Rooted 'Golden Empire State' did not flower by the treatment with $\mathrm{GA}_{3}$, but 'Oxford' did. $\mathrm{GA}_{3}+$ TIBA promoted the flowering date of the derooted plants by two days earlier than $\mathrm{GA}_{3}$ in 'Golden Empire State' and four days earlier in 'Oxford'. With roots, the difference was only one day in 'Oxford'. Plant height in both cultivars was superior with $\mathrm{GA}_{3}$ +TIBA to with $\mathrm{GA}_{3}$ treatment without roots, mainly due to the elongation of the lower internodes (Fig. 1). The fourth (top) internode was shorter instead.

\section{Triumph}

Both cultivars did not flower on water with roots, but flowered without roots (Table 2). Rooted 'Koki' did not flower even with $\mathrm{GA}_{3}$ or $\mathrm{GA}_{3}$ + TIBA treatment. Flowering rate in both cultivars was low when compared with that in the cultivars in other group. 'Kees Nelis' without roots flowered 22 and 25 days earlier with $\mathrm{GA}_{3}$ and $\mathrm{GA}_{3}$ +TIBA treatments, respectively than with water only. $\mathrm{GA}_{3}$ and $\mathrm{GA}_{3}+$ TIBA accelerated the flowering in 
derooted 'Koki' by 25 and 18 days, respectively. GA $_{3}+$ TIBA treatment resulted the tallest plants at flowering with or without root excision, but the difference in other treatments was small in 'Kees Nelis' (Fig. 1).

\section{Single late}

Flowering rate was high in any treatment in both cultivars (Table 2). Flowering date was accelerated with $\mathrm{GA}_{3}$ and $\mathrm{GA}_{3}$ + TIBA by 11 and four days with roots and by 16 and 14 days without roots, respectively in 'Ile de France'. Rooted 'Kaiserin Maria Theresia' flowered six and 0.6 days later with $\mathrm{GA}_{3}$ and $\mathrm{GA}_{3}$ + TIBA, respectively, than with water, whereas root excision gave the opposite results; flowering date was 14 and 18 days earlier with $\mathrm{GA}_{3}$ and $\mathrm{GA}_{3}+\mathrm{TIBA}$, respectively than with water. Root excision in both cultivars brought the shorter internode length of the plants grown on water, $\mathrm{GA}_{3}$ or $\mathrm{GA}_{3}+$ TIBA solution (Fig. 1).

\section{DISCUSSION}

The results indicate that the treatments with $\mathrm{GA}_{3}$ or $\mathrm{GA}_{3}$ + TIBA with or without root excision to non pre-cooled tulip bulbs are effective for rapid growth and flowering in wide range of the groups, even the response varied by cultivars, in which Darwin hybrid group showed the highest response. The role of TIBA and root excision for promoting flowering was previously clarified (Geng et al., 2005).

The difference in the response to $\mathrm{GA}_{3}$ may be related to that of cold requirement among the cultivars. 'Oxford' has longer cold requirement than 'Merry Christmas', 'Kees Nelis' and 'Ile de France' (Rees, 1977; De Hertogh, 1996). For cultivars that have longer requirement such as 'Oxford' of Darwin hybrid group, $\mathrm{GA}_{3}$ appeared to have stronger replacement effects. It is in harmony with the previous investigations that GAs had the least effects on cultivars with the shortest cold treatment and more effects on those with longer cold treatment (Hanks, 1982).

'Oxford' and 'Golden Empire State' are both the hybrids of Darwin tulips with $T$. fosteriana (Lefeber, 1960; K. Okazaki, personal communication). Darwin tulips, formerly consisting of an independent group, are now included in the Single late group. The high response of Darwin hybrid tulips to the treatments in this study, therefore, indicates that the character might have come from $T$. fosteriana.

Single early tulips grown outdoors flower earlier in spring than other groups. It means that the cold requirement of the group is less than that of other groups. Outdoor-grown Single late tulips flower late in spring, indicating that they are less sensitive to low temperature. These may be the reason that the two groups flowered on water without $\mathrm{GA}_{3}$ or $\mathrm{GA}_{3}+\mathrm{TIBA}$. The former received $15^{\circ} \mathrm{C}$ (the temperature given for growth in this study) as enough low temperature during growth and the latter might have flowered at moderate temperature like $15^{\circ} \mathrm{C}$.

Difference in the flowering behavior in September and November planting suggests the endogenous changes of metabolism in tulip bulbs during the storage at $20^{\circ} \mathrm{C}$.

Root excision rather shortens the days to flowering from planting, while TIBA rather increase flower stalk length with $\mathrm{GA}_{3}$. 


\section{REFERENCES}

Aung, L. H. and A. A. De Hertogh 1967 The occurrence of gibberellin-like substances in tulip bulbs (Tulipa sp.). Plant Cell Physiol., 8: 201-205

De Hertogh, A. A. 1996 Holland Bulb Forcer's Guide, Fifth Edition. The International Flower Bulb Centre and The Dutch Bulb Exporters Association, Hillegom (The Netherlands)

De Hertogh, A. A., L. H. Aung and M. Benschop 1983 The tulip: Botany, usage, growth, and development. Hort. Rev., 5: 45-125

Geng, X. M., K. Ii-Nagasuga, H. Okubo and M. Saniewski 2005 Effects of TIBA on growth and flowering of non pre-cooled tulip bulbs. Acta Hort., 673: 207-215

Hanks, G. R. 1982 The response of tulips to gibberellins following different durations of cold storage. Scientia Hortic., 57: 109-119

Lefeber, W. D. 1960 Raising and introducing new tulips. The Daffodil and Tulip Year Book, 25: 16-24

Rebers, M., E. Vermeer, E. Knegt, C. J. Shelton and L. H. W. van der Plas 1995 Gibberellin levels and cold-induced floral stalk elongation in tulip. Physiol. Plant., 94: 687-691

Rees, A. R. 1977 The cold requirement of tulip cultivars. Scientia Hortic., 7: 383-389

Saniewski, M., L. Kawa-Miszczak, E. Wegrzynowicz-Lesiak and H. Okubo 1999 Gibberellin induces shoot growth and flowering in nonprecooled derooted bulbs of tulip (Tulipa gesneriana L.). J. Fac. Agr., Kyushu Univ., 43: 411-418 